\title{
フッ素を含む鋳物廃砂の不溶化方法 および路盤材の製造方法
}

\author{
深山 正光 $^{1}$ ・寺埰 克博 ${ }^{2} \cdot$ 古賀 康之 $^{3}$ \\ 1財団法人福岡県すこやか健康事業団 技術部（干 839-0809 福岡県久留米市東合川六丁目 4-23） \\ E-mail:m-fukayama@sukoken.or.jp \\ 2財団法人福岡県すこやか健康事業団 技術部（广 839-0809 福岡県久留米市東合川六丁目 4-23） \\ E-mail: k-terazono@sukoken.or.jp \\ 3財団法人福岡県すこやか健康事業団 技術部（广 839-0809 福岡県久留米市東合川六丁目 4-23) \\ E-mail: y-koga@sukoken.or.jp
}

\begin{abstract}
フッ素で污染された鋳物廃砂（クロマイトサンド含有）中のフッ素の不溶化方法およびフッ素不溶化後の鋳物 廃砂を用いて路盤材を製造する方法について検討した。さらに, 実用化規模で不溶化実験と路盤材製造の実証試 験を行った。 その結果, 以下の知見を得た. (1) $\mathrm{MgO}$ の配合手順の工夫等により, フッ素不溶化に必要な $\mathrm{MgO}$ の最小混合率を得た。 (2) $\mathrm{MgO}$ と高炉セメントとの時間差混合により, 比較的高濃度（溶出濃度 : $20 \sim 70 \mathrm{mg} / l$ ) のフッ素を含む鋳物廃砂の不溶化処理が可能となった。(3) 不溶化処理後の鋳物廃砂を用い製造した路盤材は, 溶出試験においてフッ素の土壌環境基準を満足した。
\end{abstract}

Key Words : waste foundry sand, insolubilization, roadbed material, fluorine, production method

\section{1. はじめに}

近年の世界経済の発展に伴って地球規模の環境問題 が顕在化しており，地球環境問題は人間生活全般にお いて配慮しなければならない問題となっている，我が 国では太陽光発電などクリーンエネルギーにシフトし た低炭素社会構築への取り組みが始まっているが，産 業廃棄物の減量化とリサイクルの推進は，資源問題，最 終処分場の枯渇問題等と並び資源循環型社会形成推進 に欠かせない問題であり，各主体の取り組みが求めら れている．無機系の産業廃棄物として鋳物工場から排 出される鋳物廃砂は，有害物を含む場合があり，リサイ クルの障害となっている．鋳物工場では，鉄の成型性 や鋳物製品の品質向上を図るために電気炉で溶解する 工程で，鋳鉄製造用原材料と共に蛍石（フッ化カルシ ウム; $\mathrm{CaF}_{2}$ ）を混合しており，鋳物の型枠材に使用さ れる鋳物砂に蛍石由来のフッ素化合物が浸出, 析出寸 るなどして, フッ素污染鋳物廃砂が発生する事例が見 られる，我々は，北部九州にある十数社の鋳物工場か ら排出された鋳物廃砂を調査し溶出試験を行った結果, $10 \%$ 程度の割合でフッ素を検出した。数社の值は産業 廃棄物最終処分場の受け入れ基準を超え, 無害化処理 する必要があった．福岡県内の企業が排出するクロマ イトサンド含有鋳物廃砂は，フッ素溶出量が $50 \mathrm{mg} / l$ 前 後, 排出量が概衫 200 トン/月を示し, 県内の産業廃棄 物最終処分場の受け入れ基準（埋立等を行う際の「水
底土砂判定基準」） $15 \mathrm{mg} / \mathrm{l}$ を超えていた。

筆者らは，フッ素を含む鋳物廃砂の有効活用を図る 目的で鋳物廃砂に含まれるフッ素の低コスト不溶化方 法等を検討した. 比較的高濃度 $(50 \mathrm{mg} / l$ 前後) のフッ 素含有鋳物廃砂からのフッ化物イオン溶出量を土壤環 境基準值 $(0.8 \mathrm{mg} / l)$ 以下に抑制するために薬剂による フッ素の不溶化方法および不溶化処理物の有効利用方法 を検討し，いくつかの実験的成果を得たので報告する.

\section{2. フッ素不溶化に係わる既往の研究}

フッ素の不溶化方法に関する既存の研究について調 査した結果, 研究の大部分は污染土壌に関するもので あった，フッ素污染鋳物廃砂は, 各所の鋳物工場で散 見されている状況にあるが, 鋳物廃砂に含まれるフッ素 の不溶化に関する研究報告は, ほとんど確認できない.

鋳物廃砂のフッ素不溶化方法に関わる研究を推進す るために，まず污染土壌の不溶化方法について調查を

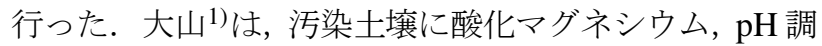
整剤および強度増加剤をフッ素污染土壌に添加・混合 することにより，フッ素を不溶化する方法を特許公報 において提示している．また松山祐介²)は，フッ素を含 む高含水污染土袞にマグネシウム系固化剂を添加・混 練した後セメント系固化剂を添加・再混練する方法を 示している. 


\section{3. 鋳物廃砂の有効利用への取り組み}

(社) 日本鋳造技術協会調査報告書 ${ }^{3)}$ によれば，平成 15 年度の愛知, 岐阜, 三重 3 県の銑鉄鋳物廃棄物の発生 量は 130 万トンで, そのうち再利用 70 万トン, セメン 卜製造に 30 万トン，路盤材に 10 万トンであり，残り 20 万トンが最終処分場で埋立処分されている. 有効利 用率は約 $85 \%$ である. 全国レベルの鋳物廃砂の発生量, 有効利用量については，鋳物廃砂はスラグ，集塵ダス ト，レンガ屑等と混じって廃棄物となっていることが あり，正確な把握は困難な状況にある.

セメント工場では, 鋳物廃砂の受け入れ要件を定め ており，環境污染を生じる可能性のある重金属分（マ ンガン, クロム, 鉛, 亜鈶, チタン等）が少ないこと, アルカリ金属分（Na, K) が $0.75 \%$ 以下であり，異物混 入がないことなどを求めている. フッ素等の有害成分 の混入も問題となるととともに鋳物廃砂の一部として クロマイトサンドを利用している場合は, クロム含量 が高いため要件を満たさない可能性が高い。このよう に廃砂受け入れに際し, 安定した量と安定した品質を 求めているため, 対象となるのは, 数百 $\mathrm{t} /$ 月程度排出で きる大規模な鋳物工場や鋳物工業協同組合などでまと めて排出している中小企業等である. 一方, まとめて 排出していない中小鋳物工場にあっては，上記セメン 卜工場の受け入れ要件に合致しない例が多いため鋳物 廃砂の有効利用は遅れており, 産業廃棄物処理費用も 多大なものになっている状況である4). その他, 路盤材 用骨材として，鋳物廃砂が利用されているが，その報 告例は一部で確認される程度である。鋳物廃砂は造粒 成形後, 加熱焼成すると土䁃改良材が得られ, 保水性, 通気性に関して他の土壌改良材より優れているが，製 造コスト面で市場参入は厳しい状況にある。窯業材料 としては，レンガやインターロッキングブロック，タイ ル等に利用でき，今後期待が持てる分野であるが，競 合材料に対しての優位性に欠ける難点がある.

\section{4. 実験方法}

\section{(1) 室内試験}

\section{a) 鋳物廃砂の性状試験}

フッ素の不溶化効果に影響すると思われる因子を選 定し(1), (2)の試験を行った.

(1) 鋳物廃砂成分試験

鋳物廃砂の成分組成の測定には, 全自動蛍光 $X$ 線分 析装置（株）リガク製 System 3270 を用いた。

(2) 粒度分布試験

粒度組成が不溶化効果に影響するか否かを見るため に測定を行った。粒度組成の測定には，レーザー回折散
乱粒度分布測定装置ベックマンコールター社製 LS-230 を用いた．分析試料は，廃砂を適量水に分散させた後， $0.1 \%$ ヘキサメリン酸ナトリウム $10 \mathrm{~m} l$ を添加して作 成した。

\section{b) 不溶化効果比較試験}

(1) 各種薬剂のフッ素不溶化効果

筆者らは, 土壌污染のフッ素不溶化事例を参考に, フッ 化物イオン溶出濃度 $12.2 \mathrm{mg} / l$ である県内企業排出のク ロマイトサンドを含む鋳物廃砂を検討対象として，以 下の薬剤類を用いて, フッ素不溶化効果を調べた. 酸 化カルシウム $(\mathrm{CaO})$, 塩化カルシウム $\left(\mathrm{CaCl}_{2}\right)$, 酸化マ グネシウム $(\mathrm{MgO})$, 塩化マグネシウム $\left(\mathrm{MgCl}_{2}\right)$, 水酸化 カルシウム $\left(\mathrm{Ca}(\mathrm{OH})_{2}\right)$, 硫酸カルシウム $\left(\mathrm{CaSO}_{4}\right)$, 炭 酸カルシウム $\left(\mathrm{CaCO}_{3}\right)$ の 7 種類の薬剤を用いた. 各薬 剂の添加量は, 土壌污染の浄化事例を参考に各 5 重量 \%添加し, 1 週間養生後溶出試験を行いフッ素の溶出量 を調べた。 不溶化効果の表示法として, フッ素溶出濃 度が不溶化処理により例えば $1 / 6$ になったとするより 6 倍濃度が希釈されたと表示した方が簡便と考え, 以下 “不溶化倍率”を用いた (不溶化倍率: 不溶化処理前フッ 化物イオン溶出濃度 $(\mathrm{mg} / \mathrm{l})$ /不溶化処理後フッ化物イオ ン溶出濃度 $(\mathrm{mg} / \mathrm{l}))$.

(2) $\mathrm{MgO}$ と高炉セメントの単独不溶化効果

不溶化処理した鋳物廃砂を路盤材製造用骨材の一部 に利用するためには, 鋳物廃砂中のフッ素を酸化マグ ネシウム（以下「 $\mathrm{MgO} 」$ と示す）で不溶化した後, セ メントによる造粒固化が必要である。筆者らは, クロ マイトサンド含有鋳物廃砂（フッ化物イオン溶出濃度 : $50.0 \mathrm{mg} / l$ ) について, $\mathrm{MgO}$ と高炉セメント（B 種）の 各単独のフッ素不溶化効果を検討した。 $\mathrm{MgO}$ を用いた のは, b)(1) の試験で不溶化効果が特に高かったためで あり，高炉セメント（B 種）を用いたのは，六価クロム の溶出が少ないこと, 路盤材としての規格 (強度, CBR 試験等）満足を図る等の理由による.

\section{c) 時間差混合試験}

b) (2) の $\mathrm{MgO}$ およびセメントの各単独不溶化試験結 果を参考に, $\mathrm{MgO}$ と高炉セメントの両方を混合し, 混 合効果の最大化を図る目的で時間差混合試験（図-1) を 行った. $\mathrm{MgO}$ と高炉セメント（B 種）を組み合わせ, 両者を約 1 週間の時間差で鋳物廃砂に混合して処理す る. 詳細は, 図-1に示す試験手順より, 乾燥した鋳物 廃砂（フッ化物イオン溶出濃度 : $31.8 \mathrm{mg} / \mathrm{l}$ ) $100 \mathrm{~g}$ をプ ラスチック製の袋に採取し, $\mathrm{MgO}$ を加え混合した後, 約 1 週間開封した状態で常温養生を行う。1 週間の時間 差で, 高炉セメントを 8.4 重量\%混合し，3 日以上養生 した. 得られた不溶化処理物は, 粉砕乾燥後, $2 \mathrm{~mm}$ の ふるいを通し，溶出試験の試料に供した. 


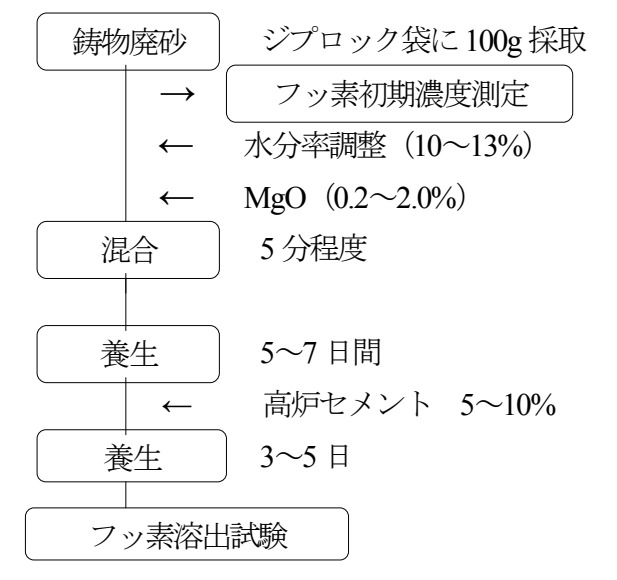

図-1 時間差混合試験手順

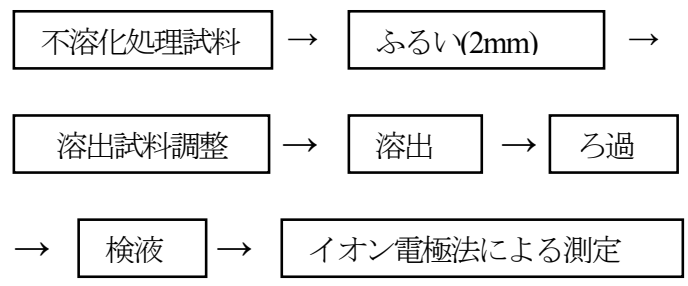

図-2 フッ素の溶出試験手順

\section{(1) 溶出試験}

室内混合試料の溶出試験は, 溶出試験方法 (環境庁告 示 46 号の測定方法5) ${ }^{5}$ ) に基づき図-2 の手順で行った.

(2) フッ素の定量

フッ化物イオンはイオンメータを用いて測定した6). イオンメータは, メトラー社製: セブンマルチ S 80 を用 いた. $\mathrm{pH}$ 等の調整のためイオン強度調整剤を $1 \sim 5 \mathrm{ml}$ 添加, 測定時の $\mathrm{pH}=5$ 前後とし測定した.

\section{d) $\mathrm{pH}$ 依存性試験}

無機系の廃棄物中のフッ素は, $\mathrm{pH}$ が異なる環境では, 溶出濃度が異なることが知られている。本試験は, 不溶 化反応時の $\mathrm{pH}$ が不溶化効果に与える影響を探るために 行った. 鋳物廃砂 10 重量\%を水に分散させた均一系に 近い鋳物廃砂分散水溶液を作り, 粉体の $\mathrm{MgO}$ を鋳物廃 砂重量の 5 重量\%混合させ, $1 \mathrm{~N}$ 塩酸および $1 \mathrm{~N}-\mathrm{NaOH}$ で 滴定したときのフッ化物イオン濃度の変化を観察した。

\section{(2) 実証試験}

\section{a) 不溶化済鋳物廃砂を用いた路盤材の製造手順}

室内試験の結果を踏まえ, 現場規模での実証試験を 行った. 試験の目的は, 室内試験結果から得られた不 溶化効果を現場規模の製造設備で確認すること，および 不溶化した鋳物廃砂に骨材，セメントを混合して，路盤 材を製造することであった．図-3に試験手順を示す．

実証試験は，事業化時の設備の規模を想定し，県内 の廃棄物中間処理会社の既存設備を用いて実施した。

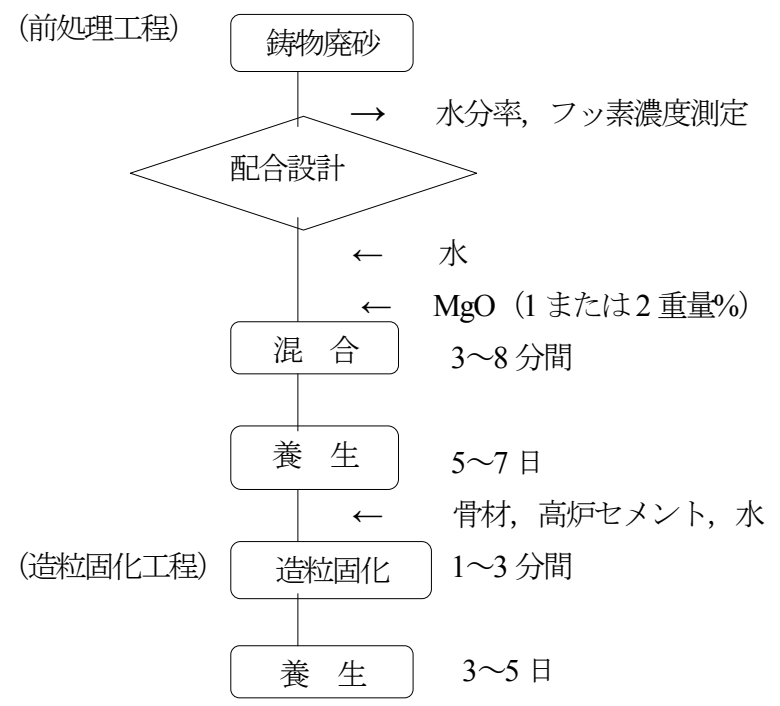

図-3 実証試験手順

表-1 実証試験配合設計表

\begin{tabular}{c|c|c|c|c|c|c}
\hline 配合 & $\begin{array}{c}\text { 高炉 } \\
\text { セメント }\end{array}$ & 水 & $\begin{array}{c}\text { 鋳 物 } \\
\text { 廃砂* }\end{array}$ & 骨材 & 重量計 & W/C \\
\hline$\left(\mathrm{kg} / \mathrm{m}^{3}\right)$ & 250 & 162 & 756 & 1512 & 2680 & 0.65 \\
\hline 比重 & 3.05 & 1 & 3 & 3 & & \\
\hline$\%$ & 9.3 & 6 & 28.2 & 56.3 & 100 & \\
\hline
\end{tabular}

* 鋳物廃砂 (処理前フッ素溶出濃度 $50 \mathrm{mg} / l$ ) は, 1 重量\%の $\mathrm{MgO}$ で不溶化処理したもの.

図-3 の実証試験手順に従い，下記のとおり実施した。

(I. 前処理工程)

(1) 鋳物廃砂（フッ素濃度 : $50 \mathrm{mg} / \mathrm{l}) 50 \mathrm{~kg}$ を, 小型ミ キサー $\left(0.2 \mathrm{~m}^{3}\right)$ に投入する.

（2）水分率が 10～13\%の範囲に入るよう水を添加する.

（3）室内試験結果に基づき， $\mathrm{MgO}$ (軽質）を鋳物廃砂 の 1 または 2 重量\%加えた後, ミキサーで 3 8 分 間混合し，冷暗所に開放系にて約 1 週間養生する.

(II. 造粒固化工程)

（1）養生済鋳物廃砂と骨材，高炉セメント，水を十分 混合して造粒固化する。

（2）造粒固化試料は， 3 日以上養生した後，粉砕し，溶 出試験，強度試験試料に供した。

各資材の配合割合は表-1 の配合設計表のとおりであ る. 配合設計は, 路盤材製造工場で通常実施されている 下層路盤材の製造方法を参考にして, 細骨材の代わりに 鋳物廃砂を使用する方法を用いた，鋳物廃砂は，前処 理工程において $\mathrm{MgO}$ で不溶化したものを使用した。骨 材分は鋳物廃砂，骨材を $1: 2$ 混合し，水セメント比を 0.65 とした。骨材の粒径は 5 20 mm であった。 セメ ントの混合比率を 9.3 重量\%と高めに設定した理由は, 強度試験を考慮したためである. 


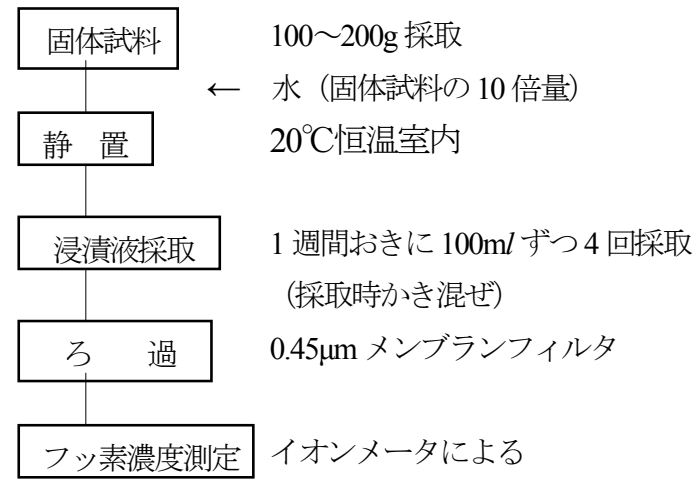

図-4 タンクリーチング試験手順

\section{b）製造した路盤材（下層路盤）の品質試験}

実証試験にて製造した造粒固化物は, 破砕処理し, 路 盤材製品に係る物理試験，化学試験（[1]〜[3]）を試験 規格に基づき実施し，品質規格の満足度を調べた。

[1] 一軸圧縮試験（試験規格 : 舗装調査・試験法便覧7) (品質規格： $1000 \mathrm{kN} / \mathrm{m}^{2}$ )

[2] 修正 CBR 試験（試験規格：JIS A 1211 ${ }^{8)}$ ) （品質規格：20\%）

[3] フッ化物イオン溶出試験（試験規格 : 環告 46 号） (品質規格 : $0.8 \mathrm{mg} / \mathrm{l}$ )

\section{(3) 環境安全性試験9)}

不溶化した鋳物廃砂を通常環境中で路盤材等に使用 した場合，フッ素の再溶出が環境安全上の問題となら ない程度であれば，当該製造物はリサイクル品として 使用できるものと考えられる.タンクリーチング試験 は，セメント系固化材による改良土の六価クロムの溶 出試験に用いられている方法（環告 46 号）であるが, この方法に準拠して路盤材の溶出試験を行った。当該 手法は，塊状の不溶化済試料を通常の環境中に存在す る程度の $\mathrm{pH}$ 值を示す水に 4 週間浸漬させたときの溶 出濃度の変化を観察するもので, 環境安全性の厳密な 判定とはならないが, 一定の目安程度の評価を得る目 的で実施したものである。具体的には，製造した塊状 固形の路盤を一定重量採取し，その 10 倍量の水に浸漬 させ 1 週間おきに水を採取し, フッ化物イオンの溶出 濃度を測定する。溶出液の $\mathrm{pH}$ は, 環境庁告示法には, 5.8〜6.3 と規定されているので， 5.9 に調製した水を用 いた。図-4に試験手順を示す.

\section{5. 実験結果}

(1) 室内試験

a) 鋳物廃砂の性状試験

(1) 鋳物廃砂の成分

表-2に検討に用いた鋳物廃砂の分析結果を示す．表一
表-2 鋳物廃砂成分

\begin{tabular}{c|c|c|c}
\hline 元素名 & 含有率 $(\%)$ & 化合物名 & 含有率 $(\%)$ \\
\hline $\mathrm{Si}$ & 32 & $\mathrm{SiO}_{2}$ & 45 \\
\hline $\mathrm{Cr}$ & 26 & $\mathrm{Cr}_{2} \mathrm{O}_{3}$ & 20 \\
\hline $\mathrm{Fe}$ & 25 & $\mathrm{Fe}_{2} \mathrm{O}_{3}$ & 18 \\
\hline $\mathrm{Al}$ & 5.7 & $\mathrm{Al}_{2} \mathrm{O}_{3}$ & 7.3 \\
\hline $\mathrm{Mg}$ & 3.5 & $\mathrm{MgO}$ & 4.0 \\
\hline $\mathrm{Ca}$ & 2.2 & $\mathrm{CaO}$ & 1.8 \\
\hline $\mathrm{Mn}$ & 1.9 & $\mathrm{MnO}$ & 1.3 \\
\hline \hline 合計 & 97.7 & & 97.4 \\
\hline
\end{tabular}

* 蛍光 X 線分析（理学 System 3270E）による.

表-3 クロマイトサンド含有鋳物廃砂の粒度組成

\begin{tabular}{c|c|c|c|c|c}
\hline$\%>$ & 10 & 25 & 50 & 75 & 90 \\
\hline $\mathrm{Mm}$ & 258 & 140 & 35.1 & 7.40 & 2.59 \\
\hline
\end{tabular}

・平均径 : $85.7 \mu \mathrm{m}$ ・モード : $269 \mu \mathrm{m}$

・中位径 : $35.1 \mu \mathrm{m}$-平均径/中位径 : 2.4

*レーザー回折散乱粒度分布測定装置 (ベックマンコー ルター社製 LS-230）による.

2 より, 鋳物廃砂の成分で, 含有量の多い順に, シリカ $\left(\mathrm{SiO}_{2}\right)$, 次いでクロム $\left(\mathrm{Cr}_{2} \mathrm{O}_{3}\right)$, 鉄 $\left(\mathrm{Fe}_{2} \mathrm{O}_{3}\right)$, であっ た。クロムは，クロマイトサンドを含むため高值を示 し，鉄は，鋳物製造工程で溶解した鉄成分の混入のため と考えられた．鋳物砂には，天然砂（原料は山砂，天然 珪砂）と合成砂（原料は人工珪砂）があり，山砂の $\mathrm{SiO}_{2}$ 含有率は, 75〜85\%, けい砂で 85～98\%であるとされ ている ${ }^{10)}$. 当該鋳物廃砂は, クロマイトサンド含有に より, 山砂に比べ $\mathrm{SiO}_{2}$ の含有率が低く, $\mathrm{Cr}_{2} \mathrm{O}_{3}, \mathrm{Fe}_{2} \mathrm{O}_{3}$, の含有率が高くなったものと考えられる.

(2) 鋳物廃砂の粒度組成

表-3 に試験用鋳物廃砂の粒度組成測定結果を示す。 結果より，不溶化試験に用いた鋳物廃砂（クロマイト サンド含有）の粒度は中位径が $35.1 \mu \mathrm{m}$ であり，35 $\mu \mathrm{m}$ 前後の粒径が主流を占めるが, 平均粒径は $85.7 \mu \mathrm{m}$ とや や大きく, 10\%以上含まれている $200 \mu \mathrm{m}$ 以上の粒子の 影響が大きかった. $3 \mu \mathrm{m}$ 以下の粒子も $10 \%$ 以上含まれ ていた。この鋳物廃砂と比較の意味で別の鋳物工場で 産出される山砂主成分の型ばらし集塵ダストの粒度を 測定した結果, 中位径が $9.25 \mu \mathrm{m}$, 平均径が $11.8 \mu \mathrm{m}$ で あった。この型ばらし集塵ダストの不溶化効果は, 研 究対象の鋳物廃砂（クロマイトサンド含有）の不溶化 効果に比べて約 $60 \%$ であた。 すなわち，不溶化材の 混合率が同一の場合，粒径が小さい鋳物廃砂の方が不 溶化効果は低下した。これより，不溶化対象の鋳物廃 砂の粒度組成は，不溶化効果に影響する一因子である 


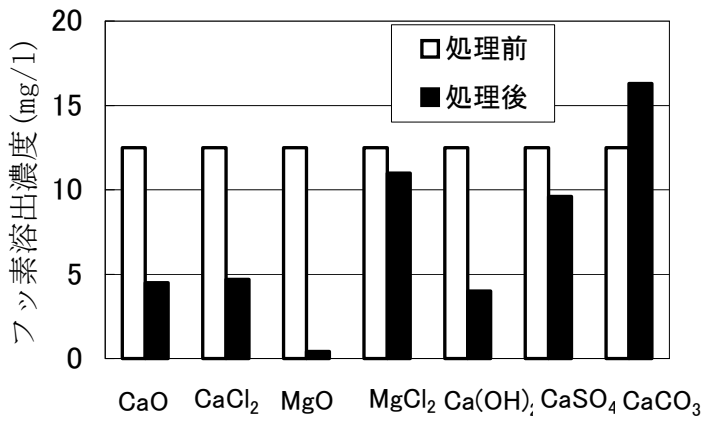

図-5 各種薬剂のフッ素の不溶化効果

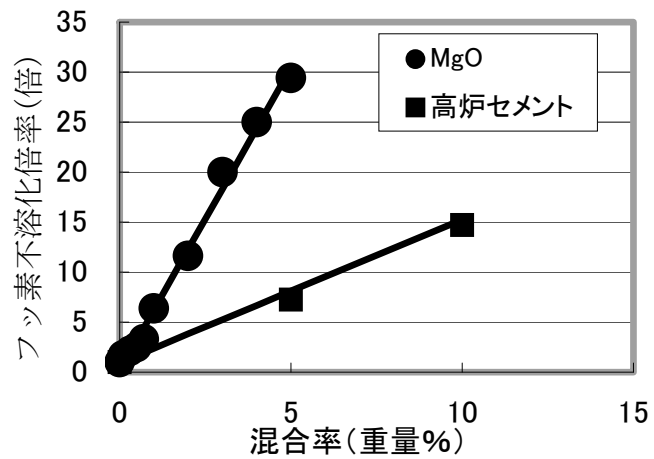

図-6 MgO および高炉セメントのフッ素不溶化効果

と考えられた。このことより，フッ素で污染された鋳 物廃砂の粒度が小さいほど, 污染濃度が高いことが推 定されるが，特定の鋳物廃砂の粒度と污染濃度との関 係については今後の検討課題である.

\section{b) 不溶化効果比較試験}

(1) 各種薬剤のフッ素不溶化効果

各種薬剤のフッ素不溶化試験結果を図-5 に示す，結 果より, フッ素溶出量は, 炭酸カルシウム $\left(\mathrm{CaCO}_{3}\right)$ 混合 では，ほとんど効果がなく，塩化マグネシウム $\left(\mathrm{MgCl}_{2}\right)$, 硫酸カルシウム $\left(\mathrm{CaSO}_{4}\right)$ 混合は, わずかな効果しか見 られなかった。

一方, 酸化カルシウム $(\mathrm{CaO})$, 塩化カルシウム $\left(\mathrm{CaCl}_{2}\right)$, および水酸化カルシウム $\left(\mathrm{Ca}(\mathrm{OH})_{2}\right)$ 混合の場合, 薬剤 混合前に比べ $1 / 3$ 程度に減少した。 $\mathrm{MgO}$ (軽質) 混合の 場合は, 混合処理後のフッ化物イオン溶出濃度 $0.4 \mathrm{mg} / \mathrm{l}$ で混合処理前の約 1/30 であった。この結果より, $\mathrm{MgO}$ のフッ素不溶化効果は, 他の薬剤に比べ特異的に高い ことが判った。

(2) $\mathrm{MgO}$ と高炉セメントの不溶化効果

$\mathrm{MgO}$ およびセメントを別々に鋳物廃砂に混合して, フッ化物イオンの溶出量を調べた. 薬剂混合量と不溶化 倍率 (不溶化前溶出量/不溶後溶出量) の関係を図-6に 示寸.

図-6より, $\mathrm{MgO}$ の混合量とその不溶化倍率は直線関 係にあり, 回帰式: $Y=6.06 X+0.157$, 相関係数 : 0.9961

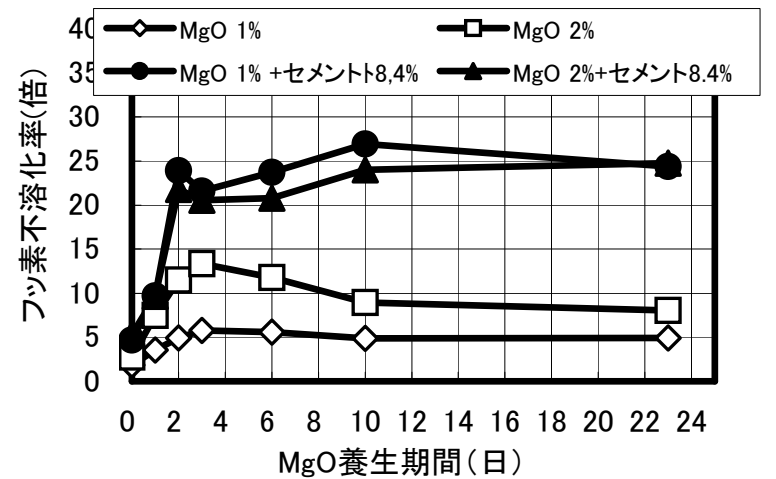

図-7 $\mathrm{MgO}$ 養生日数とフッ素不溶化率の関係

であり，混合率が 0 5 重量\%の範囲では $\mathrm{MgO}$ の混合 量に比例して不溶化倍率が増加する. 従って $\mathrm{MgO}$ を 1 重量\%混合すると, フッ化物イオン不溶化倍率は約 6 と なることが判った。 また，セメント混合の場合も混合 率が 0 10 重量\%の範囲では直線関係を示し, 回帰式: $Y=1.43 X+0.963$, 相関係数 : 0.9951 であった. 回帰 式より, 高炉セメント単独 $1 \%$ 混合で, フッ化物イオン 不溶化倍率は約 2.4 となった。

\section{c) 時間差混合試験}

$\mathrm{MgO}$ と高炉セメントの両方をフッ素含有鋳物廃砂に 短時間に連続混合した結果, $\mathrm{MgO}$ 単独混合の場合と同 程度の不溶化効果しか得られなかった。この原因を探る ために $\mathrm{MgO}$ 混合後, 一定時間をおいて高炉セメントを 混合する時間差混合試験を行った。その結果を図-7に 示す。結果より, $\mathrm{MgO}$ 単独混合（1\%または $2 \%$ 混合） によるフッ素の不溶化倍率は，1３ 日間で最高值に達 し, その後漸減傾向にあった。おおよそ 10 日以上経過 すればフッ素の溶出量は一定值に落ち着く傾向を示し た．最初粉体であった鋳物廃砂は，水および薬剤を混 合後, 数日間風乾すると手で壊せる程度の固化体となっ た. $\mathrm{MgO}$ とセメントの時間差混合試料は, 養生期間 1 $\sim 3$ 日間は, $\mathrm{MgO}$ 単独混合の場合と同様に変化が大き $<, 7$ 日程度以上経つと安定した不溶化倍率を示し, 23 日後には, $\mathrm{MgO}$ 混合量 $1 \%, 2 \%$ 両方とも不溶化倍率, 約 25 倍を示した。 寸なわち, 安定期ではフッ化物イオ ン溶出濃度は, 不溶化処理前の溶出濃度のほぼ $1 / 25$ を 示した. $\mathrm{MgO} 1 \%$ 混合の場合, セメントを時間差で混合 すれば, $\mathrm{MgO}$ 単独混合の場合に比べ, 不溶化倍率は約 5 倍であった。 なお，再現性を確認するため 3 度のくり 返し実験を行い, 結果はほぼ同様であった。

鋳物廃砂の不溶化反応は, 厳密には水酸化マグネシウ ムへのフッ化物イオンの吸着反応と考えられるが, 6.(1) a) に述べる水を介在した固-固反応であり, 水中にイオ ン化している有害物を固体に吸着させるような固-液反 応とは反応機構が異なっている。また，廃棄物のよう 


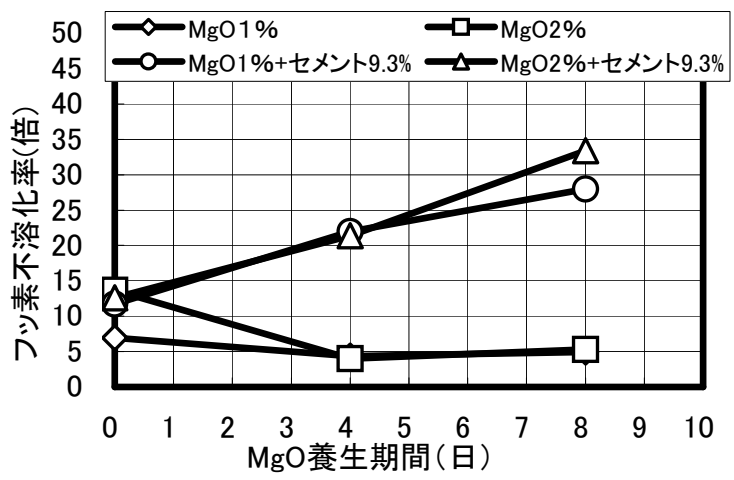

図-8 実証試験のフッ素不溶化率

な複雑組成を持つ試料の不溶化反応は，フッ化物イオン 以外の共存物質の影響もある。ここでは，一つの鋳物 廃砂について不溶化効果の検討をしたものであり, フッ 化物イオン濃度を变化させた速度論的な検討および不 溶化（吸着）機構の検討は行っていない.

\section{(2) 実証試験}

\section{a) 路盤材からのフッ化物イオンの溶出}

図-3 の実証試験手順，表-1 の配合設計表に従い製造 した路盤材の溶出試験結果を図-8に示す。結果より, $\mathrm{MgO}$ とセメント両者の時間差混合において, $\mathrm{MgO}$ 混合 後の養生期間を 8 日以上とれば, フッ化物イオン溶出濃 度は路盤材製造前が $12 \mathrm{mg} / l$, 製造後が $0.24 \mathrm{mg} / l$ であり, 不溶化倍率は 25 倍以上となった。この結果は，室内試 験の時間差混合試験結果（図-7）と似通っていた。路盤 材のフッ化物イオンの溶出濃度を環境基準值 $(0.8 \mathrm{mg} / \mathrm{l})$ 以下にするには，不溶化倍率が 25 倍であるので，鋳物 廃砂からの不溶化前溶出濃度は, $0.8 \times 25=20 \mathrm{mg} / l$ 以 下であればよい，厳密には，上記の $\mathrm{MgO}$ とセメントの 不溶化効果に加え，路盤材製造においては，粗骨材の 混合による希釈効果も加わる.

図-8 の実験条件では, 路盤材全重量に対する鋳物廃砂 の重量比率は, 表-1 の配合設計表より 756/2 680 = 0.28 （重量比率補正值）であり，溶出試験で得られる值は $0.8 \times 0.28=0.224 \mathrm{mg} / l$ と計算され，実験值 0.24 に近い 結果であった.

以上の結果より，表-1の配合設計で路盤材を製造し た場合, フッ化物イオンの初期濃度が $20 \mathrm{mg} / l \div 0.28 \doteqdot$ $70 \mathrm{mg} / l$ 以下の範囲では, 環境基準值 $(0.8 \mathrm{mg} / l)$ を満足 する路盤材の製造は可能であることが判った.

\section{b) 路盤材の物理試験結果}

実証試験で製造した造粒固化物を, 破砕処理し, 路 盤材製品に係る一軸圧縮強度試験，修正 CBR 試験を実 施した結果は，下記のとおりであった。

[1] 一軸圧縮試験 $\left(6100 \mathrm{kN} / \mathrm{m}^{2}\right)$

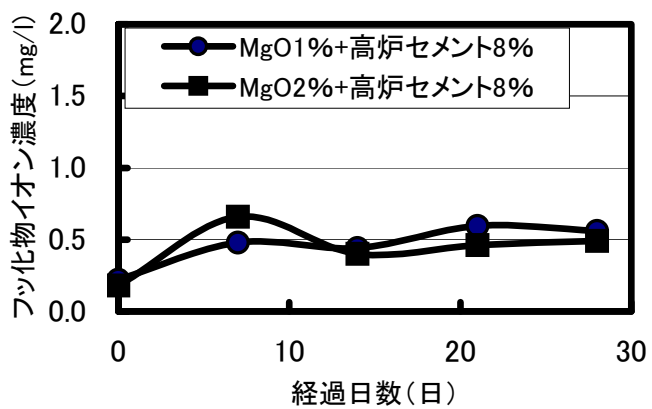

図-9 路盤材のタンクリーチング試験

[2] 修正 CBR 試験（121\%）

[3] フッ化物イオン溶出試験 $(0.24 \mathrm{mg} / l)$

[1]，[2]，[3]の試験結果は，下層路盤材の製品規格を 充分満足し, 現場で使用できる品質を備えていること を示した。

\section{(3) 環境安全性試験}

(1) タンクリーチング試験

図-9に不溶化鋳物廃砂を用いて製造した路盤材を塊 状で 4 週間水に浸漬させたときの, 浸漬液中のフッ化 物イオン濃度の変化を示す。

結果より，1４ 週における各フッ化物イオン溶出濃 度は，1\% MgO，2\% $2 \%$ 両者ともに $0.4 \sim 0.6 \mathrm{mg} / l$ の範 囲で推移した。 また, 4 週以降のフッ化物イオン濃度 は, $0.5 \mathrm{mg} / \mathrm{l}$ 付近で推移した. これより, $\mathrm{pH} 5.88$ の水に よる 4 週間タンクリーチング試験は， $\mathrm{MgO} 1 \% ， 2 \%$ 混 合両試料とも溶出濃度に大差はなく環境基準值 $0.8 \mathrm{mg} / l$ を満足した。この試験に用いた鋳物廃砂の不溶化処理 前の溶出濃度は $50 \mathrm{mg} / \mathrm{l}$ であり, 不溶化倍率が 25 であ るので環境庁告示 46 号の溶出試験であれば $2 \mathrm{mg} / \mathrm{l}$ の溶 出量となるが, 本タンクリーチング試験は, 試料の大 きさが塊状（約 $37.5 \mathrm{~mm}$ 以下）であり, 静置溶出であ るため, 約 $1 / 4$ の溶出量になったものと考えられた。溶 出濃度が 7 日でピークに達し, その後は $0.5 \mathrm{mg} / l$ 程度 で推移したことから，フッ化物イオンは７日でほとん ど溶出が終わり, その後の溶出はほとんど無視できる 結果であった。

\section{6. 考察}

(1) MgO のフッ素不溶化能力

a) フッ素と $\mathrm{MgO}$ の反応

$$
\mathrm{MgO}+\mathrm{H}_{2} \mathrm{O}+x \mathrm{~F} \rightarrow \mathrm{MgF}_{x}(\mathrm{OH})_{2-x}+x \mathrm{OH}^{-}
$$

式(1)は, MgO〔酸化マグネシウム: 慣用名マグネシ ア〕が水と反応し, $\operatorname{Mg}(\mathrm{OH})_{2}$ 〔水酸化マグネシウム : 慣 用名ブルーサイト] となり, その際フッ化物イオンが 
$\mathrm{OH}^{-}$基とイオン交換してブルーサイトに取り込まれる 反応を示している．マグネシアによるフッ素の固定機 構は, 上式のような反応によると考えられており，実 験では化学吸着であることも指摘されている11).

\section{b) フッ素と $\mathrm{MgO}$ の量反応関係}

いま, フッ素の不溶化反応が，a)の式(1)の化学量論 に従って進行するとする. $1 \mathrm{~mol} の \mathrm{MgO}$ は， $x(\mathrm{~mol}) の$ フッ素を固定できる. $\mathrm{MgO}$ の式量 40.3, フッ素の原子 量 19.0 であるので $19.0 x$ ( $\mathrm{g}$ ) のフッ素を固定するため, マグネシア $1 \mathrm{~g}$ あたりフッ素 $0.47 x(\mathrm{~g})$ のフッ素が固定 される. 式(1)におけるフッ素の係数 $x$ の推定值につい ては，以下のごとく算出した．

まず，筆者らは， 5.(1) c) で使用した鋳物廃砂を対象 に, 物砂 $100 \mathrm{~g}$ 中のフッ素の総量推定を行った. 鋳物廃 砂中のフッ素の総量を求めるために, くり返し溶出試 験（同じ廃砂について続けて数回溶出寸る）を行った. 初回の溶出濃度は $31.8 \mathrm{mg} / l$ であり, 各回の溶出操作に おける溶出率の平均值は, 約 $70 \%$ あ゙った。この結果 より, フッ素総量 $(\mathrm{mg})=$ 初期溶出量 $(\mathrm{mg})+$ 初期溶出 量 $(\mathrm{mg}) \times \sum(0.3)^{n}=31.8+31.8 \times \sum(0.3)^{12} \doteqdot 31.8 \times 1.5=$ $47.7 \mathrm{mg}$ となった。これより, 鋳物廃砂 $100 \mathrm{~g}$ に $1 \mathrm{~g}$ の $\mathrm{MgO}$ を混合したときの, 混合前後のフッ化物イオン総量 (g) は，それぞれ $47.7 \mathrm{mg}, 5 \mathrm{mg}$ であった. よって, $\mathrm{MgO}$ $1 \mathrm{~g}$ により除去されたフッ素量は, 47.7-5 = 42.7 mg とな る. また, 式(1) は $\mathrm{MgO}$ (分子量 40.3) と $x \mathrm{~F}$ (分子量 19x) のモル比で反応が進行するので, $40.3: 19 x=1: 0.0427$ の比例関係が成立する．これより $x$ の值は 0.091 であっ た.この結果は, Maliyekkal らの研究11)で示されたマ グネシア修飾活性アルミナの場合の 0.021 に比べて約 4.3 倍であった

一方, 図-7, 図-8 の $\mathrm{MgO}$ 単独不溶化効果では, 1 週 間以上養生すれば $1 \%$ 混合と $2 \%$ 混合に明瞭な差がなく, $1 \%$ 混合で不溶化に必要な $\mathrm{MgO}$ 量を満たしていると判 断された．また， $\mathrm{MgO}$ 混合率を0.1〜2.0\%まで変化さ せた不溶化実験を別途実施して, $\mathrm{MgO}$ の不溶化効果は 0.5 重量\%以上で十分発揮されることも確認している. これらより, 本実験条件では, $\mathrm{MgO}$ の最小混合率は, $0.50 \sim 1.0$ 重量\%程度と判断した.

\section{(2) $\mathrm{pH}$ と不溶化効果について}

図-10に $\mathrm{pH}$ とフッ化物イオン濃度との関係を示寸. 図-10 より, 混合溶液は当初 $\mathrm{pH}$ が 10.5 程度であるが, $1 \mathrm{~N}-\mathrm{HCl}$ で滴定していくと, フッ化物イオン濃度は, 上昇 $\iota \mathrm{pH}=8.5$ 付近で極大值（約 $40 \mathrm{mg} / l$ ）を示す．滴定を 進め $\mathrm{pH}=5$ 以下では $1 \mathrm{mg} / l$ 以下を示寸 (フッ化水素イ オンの生成). 次に $1 \mathrm{~N}-\mathrm{NaOH}$ で滴定すると, フッ化物 イオン濃度は再び $\mathrm{pH}=8 \sim 9$ で極大值を示寸.さらに 滴定を進めるとフッ化物イオン濃度は, 減少し $\mathrm{pH}=10$

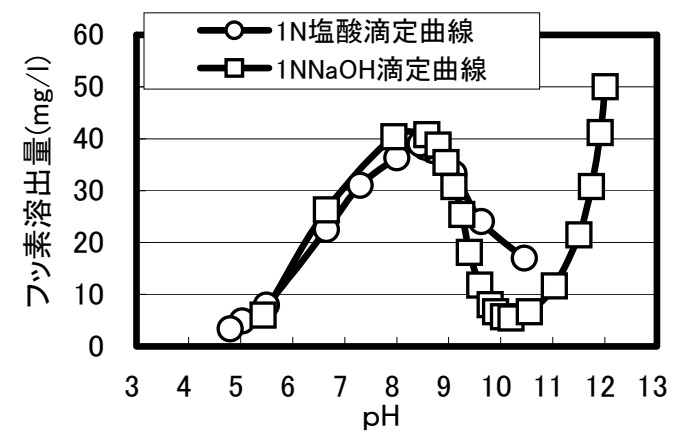

図-10 鋳物砂 $+1 \% \mathrm{MgO}$ 分散水溶液中フッ化物イオン濃度の $\mathrm{pH}$ 依存性

付近で最低值を示す．その後 $\mathrm{pH}$ を高くするとフッ化物 イオン濃度は急上昇していく.

筆者らは，上記の実験的事実より，フッ素含有鋳物 廃砂に $\mathrm{MgO}$ を混合し不溶化する際に, 鋳物廃砂の $\mathrm{pH}$ が 10 付近であれば, フッ素の不溶化効果が最も高まる と考えた．本研究に用いた鋳物廃砂の $\mathrm{pH}$ は 10.5 であ り, $\mathrm{MgO}$ を混合しても $\mathrm{pH}$ は 10 付近に落ち着き不溶化 効果が発揮されたものと考えられた. しかし, 時間差 混合においては, 高炉セメントをさらに追加混合する ことで, 混合系のアルカリ化 $(\mathrm{pH}=11.5)$ が進行し, ブルーサイトに結合している水酸イオンが遊離のフッ 化物イオンとイオン交換する反応が起こりにくくなり, $\mathrm{MgO}$ と高炉セメントの複合効果が抑制されたものと考 えられた。

\section{(3) 時間差混合の効果について}

図-7（Mg0のみ混合した場合を参照のこと）より， $\mathrm{MgO}$ 混合後 1〜3 日間は, 不溶化効果が増すがそれ以 降は, 逆に効果の減少が見られる. その原因の一つと して次の事象がある. 鋳物廃砂, $\mathrm{MgO}$ および水の 3 成 分混合系の $\mathrm{pH}$ は, $\mathrm{MgO}$ 混合直後よりも時間が経過す ると低下寸る.これはケイ酸塩主体の鋳物廃砂自体の 緩衝作用により, 混合物の $\mathrm{pH}$ を中性に戻す力が働くた めである.この 3 成分系の実験では, $\mathrm{MgO}$ 混合直後に pH が 10.7 であったが，数時間で 9.3 まで低下した.

(2) に示すフッ化物イオンと $\mathrm{MgO}$ 混合系でフッ化物 イオン濃度が最も低下するのは, $\mathrm{MgO}$ 混合直後の $\mathrm{pH}$ が 10 付近であった. その後 $\mathrm{pH}$ 值が降下し, フッ化物 イオン濃度がやや高くなる時期すなわち不溶化効果が 減少し終わる時期は, $\mathrm{MgO}$ の反応の終息期と判断され る.この時期にセメント混合（時間差混合）を行えば, 6.1 a) の式 (1) 以下に示寸ブルーサイトへのフッ化物イ オンとセメント由来の $\mathrm{OH}$ 基の競合反応が避けられ, 不 溶化効果の低下を抑制することが可能である. 


\section{7. 結論}

研究結果をまとめると，以下のとおりである.

(1) $\mathrm{MgO}$ 混合によるフッ素の不溶化効果は, $\mathrm{MgO}$ 混 合時の鋳物廃砂（クロマイトサンド含有）の $\mathrm{pH}$ が 10 付近で最大を示した.

(2) 不溶化に必要な $\mathrm{MgO}$ の最小混合率は, フッ素溶 出量が $0 \sim 50 \mathrm{mg} / l$ の鋳物廃砂の場合, $0.5 \sim 1.0$ 重 量\%であり, 安全率を 3 とすれば, 約 1.0 重量\%で あった。ただし，上記の值を得るには鋳物廃砂と $\mathrm{MgO}$ の混合が入念になされる必要がある.

(3) $\mathrm{MgO}$ の最小混合率は, 鋳物廃砂の種類や性状によっ て変わるので, 本研究で示した方法等により, 最 小混合率を求め過剰混合の防止を図ることで，不 溶化処理の効率化が期待できる.

(4) $\mathrm{MgO}$ と高炉セメントの時間差混合法において, 不 溶化効果を最大にするには, $\mathrm{MgO}$ 混合後の養生期 間を 3 日以上，望ましくは 7 日以上とすればよい.

(5) 不溶化前フッ素溶出量が $20 \mathrm{mg} / \mathrm{l}$ 以下であれば, 時間差混合法により，フッ素溶出量を環境基準值 $(0.8 \mathrm{mg} / l)$ 以下とすることが可能である.

(6) $\mathrm{MgO}$ と高炉セメント時間差混合法による鋳物廃砂 のフッ素不溶化処理効果に影響を及ぼす因子とし て，(1) 鋳物廃砂の粒度組成，（2）不溶化反応時の $\mathrm{pH}$ ，(3) 不溶化剂混合時の水分率，(4) $\mathrm{MgO}$ 混合後 の養生期間等が挙げられる.

（7）時間差混合の手法を用いて路盤材を製造する場 合，本研究で実施した鋳物廃砂の混合比率では， 不溶化処理前の鋳物廃砂からのフッ素溶出濃度が 約 $70 \mathrm{mg} / l$ 以下であれば, 路盤材のフッ素溶出濃度 を環境基準值以下にすることは可能であった。

（8）フッ素は，ブルーサイトと経時的に強固な結合を 形成し，高炉セメント混合によるアルカリ雰囲気 では安定状態が期待される.しかし, 路盤材の長 期環境安全性については, 今回のタンクリーチン グ試験では明確な評価は得られなかった。

本研究では，フッ素污染鋳物廃砂の不溶化処理コス トの削減と, 路盤材への有効利用が可能であることを 確認したが, 長期の環境安全性の評価は今後の課題と なった。今回は鋳物廃砂を研究対象にしたが, 鋳物廃 砂より排出量の多い鉄鋼スラグでも同様なフッ素污染
が報告されている ${ }^{12)}$. スラグ等への対応は，今後の課 題である。本技術が廃棄物処理の現場で活用され，産 業廃棄物の削減, 資源の循環利用の一助となることを 期待する. 最後に, 本研究は, 室内試験と福岡県の企 業で実施した実証試験両方において, 不溶化効果を確 認したため，現在特許出願中である.

謝辞： 本研究の実施に関わり数々の指導を頂きまし た九州大学農学院和田信一郎教授に深謝申し上げます. 中村又善顧問および実験研究の実施に協力頂いた環境 科学センターの環境調査課, 分析課他各課の職員諸氏 に対し感謝の意を表します。また，実証試験の実施に 際し，資材および機材の準備に協力をいただいた瀬口 舗道株式会社様に厚く御礼申し上げます.

\section{参考文献}

1) 大山將 : 特許第 4109017 号, 污染土畩の固化 - 不溶化方 法，2008.

2) 松山祐介 : 特許第 3972013 号, 污染土畩の固化 - 不溶化 処理方法, 2007.

3) 財団法人日本鋳造技術協会 : [平成 15 年度経済産業省委 託事業], 使用済み鋳物砂等の再利用・リサイクルシステ 么調査報告書, pp.5-11，2006.

4) 村川悟他 : 鋳造工場から排出される廃砂の有効利用に関 する調査, 三重県科学技術振興センター研究報告 No.26, pp.47-50, 2002.

5) 環境省 : 環境庁告示第 46 号.

6) 国土交通省 : 河川水質試験方法 (案), 河川管理業務連絡 会編 785, 1998.

7）日本道路協会編：舗装調査・試験法便覧，[4]-38～[4]-41, 2007.

8）日本道路協会編：舗装調查・試験法便覧，pp.[1]-190～ [1]-198， [4]-5〜[4]-9， 2007.

9) 乾徹, 有倉宏史, 鑪迫典久, 田坂行雄 : 廃棄物再生資材 の新たな環境影響試験法とその適用事例, 地盤工学会誌, Vol.56, No.8, pp.16-19, 2008.

10）厚生労働省：業種別の原材料・工程と対策, 作業環境, Vol.8, No.1, pp.48-49, 1987.

11) Maliyekkal, S. M., Shukla, S., Philip, L. and Indumathi, M. N.: Enhanced fluoride removal fromdrinking water by magnesia-amended activated alumina granules, Chemical Engineering Journal, Vol.140, pp.183-192, 2008.

12）嘉門雅史，乾徹，宮城大助，勝見武 : 鉄鋼スラグの地盤 材料としての有効利用に伴うフッ素の溶出挙動とその環 境影響の評価, 京都大学防災研究所年報, 第 47 号 B, pp.121-132, 2004.

(2011.8. 26 受付) 


\title{
INSOLUBILIZATION METHOD OF THE FLUORINE IN WASTE FOUNDRY SAND AND THE PRODUCTION METHOD OF THE ROADBED MATERIAL
}

\author{
Masamitu FUKAYAMA, Katsuhiro TERAZONO and Yasuyuki KOGA
}

We have studied how the fluorine-insoluble in the waste foundry sand (chromite sand) and production method of the roadbed material with insolubilized waste foundry sand. And we got following knowledges.

(1) We found a minimum mixing rate to insolubilize of fluorine in the waste foundry sand by the ingenuity of mixing procedure.

(2) Now we can insolubilize the waste foundry sand including comparatively high concentration fluorine (elution concentration: $20 \sim 70 \mathrm{mg} / l$ ) by the mixing time difference of $\mathrm{MgO}$ and blast furnace cement.

(3) In the verification test the roadbed material made from the insolubilized waste foundry sand satisfied reference value of environment safety. 